\title{
8. The growth of private actors in education in East Africa
}

\section{Linda Oduor-Noah}

\section{INTRODUCTION}

East African countries have thus far committed to achieving Education for All (EFA) through the signing of various treaties and conventions, ${ }^{1}$ each one pronouncing the State as the sole custodian and entity obligated to deliver on the right to education (Oketch et al., 2010b). More recently, these commitments have been given further onus through the Sustainable Development Goals, which commit countries to achieving inclusive and equitable quality for all. Despite these commitments, only 68 per cent of school-age children in sub-Saharan Africa attend school (Abuya et al., 2014; Phillips, 2013). Furthermore, the declining quality of education despite current investments remains a serious concern (Languille, 2014; Wilson-Strydoma \& Okkolin, 2016; Zuze \& Leibbrandt, 2011). Private actors are now increasingly put forward as the solution to this crisis, based on a rationale of competitive markets producing a higher quality offering (Bellei \& Orellana, 2014). However, this chapter will show that any benefits conferred by the current mix of education provision vary in scope, value, and impact.

Given that human rights law allows for the ownership and operation of schools by private entities, the State remains obligated to ensure that all actors within the education sector observe human rights principles (the 2019 Abidjan Principles). This chapter consolidates literature that

\footnotetext{
Including the Universal Declaration of Human Rights (1948 Article 26); International Covenant on Economic, Social and Cultural Rights (1966); International Convention on the Rights of the Child (1989), and agreements made at various fora such as the Jomtien Education for All (1990) and the Dakar Framework for Action (2000).
} 
examines trends in the growth of private actors, factors influencing this growth, and the impact of this growth on primary and secondary education in East Africa over a seven-year period. The chapter will also explore the extent to which East African governments are meeting this obligation. Examples from countries in the region - Kenya, Uganda, Tanzania, Ethiopia, Rwanda and South Sudan - illustrate each of these issues.

\section{CONTEXT}

This section presents a broad overview of the education landscape in the East African region providing a historical description of the social, political and economic contexts leading to national commitments to free basic education as well as those that had a significant bearing on the evolution of private education. This analysis begins during the colonial era.

\subsection{Education Agendas from the Colonial Period to Post-Independence}

While various forms of education existed prior to colonisation, education in the colonial era took an exclusive form characterised by racial segregation and barriers to progression for indigenes (Somerset, 2007; Weaver, 2011). For instance in Kenya, colonial education was concentrated in urban areas neglecting semi-arid areas, while in Uganda, education was provided at a fee as far back as the pre-colonial period. Ethiopia, however, had universal education provision as early as 1908 with further developments driven by Theodore Shultz inspired schools of thought in the 1950s, which called for higher public spending on education. Subsequently, universal education became a core component of the post-colonial project proposed by newly elected presidents throughout the region. For them, education would provide long-denied opportunities, reaffirm national identity, and increase the capacity of the economy to cater to the needs of the newly independent State. Each country approached the task with its own political philosophy: Tanzania and Uganda were described as having socialist leanings, while Kenya was described as being more capitalist in orientation (Lelei \& Weidman, 2012; Mtonga, 1993; Oketch \& Rolleston, 2007; Wiegratz, 2019). Provision increased first, followed by a wave of fee abolitions in the 1960s and 1970s. This led to surging enrolments (Anangisye, 2010; MOEC, 2000; Mtahabwaa \& Rao, 2010; Oketch \& Rolleston, 2007; Vavrus, 2002; Wambayi, 2004). High enrolment further illustrated the 
extent to which school fees had acted as a barrier to accessing education at the time.

In the 1980s, Structural Adjustment Policies (SAPs) took hold in Uganda and Kenya, with States instructed to make changes to their macro-economic environment. Governments were expected to reduce inflation, "liberalize, privatize [and] deregulate" (Vavrus \& Moshi, 2009, p. 32; see also Phillips, 2013; Wedin, 2004). This re-introduced user fees across public services and set in motion a decline in education expenditure. For instance, in Uganda, education expenditure declined from 5.1 per cent to 2.5 per cent between the years 1988 and 2000 (Penny et al., 2008; Riep \& Machacek, 2016). Unlike its neighbours, Tanzania resisted these prescriptions resulting in rising tensions between international and bilateral donors and the president. This led to a decline in development support exacerbating the economic crisis in Tanzania overall (Lofchie, 2014; Nyerere, 1967). The tensions only began to ease when President Nyerere's successor came into power in 1985 and accepted the World Bank and International Monetary Fund's loan terms and conditions. Tanzania became a prime example in the region of how donor pressure could shift national economic policy (Anangisye, 2010; Lofchie, 2014; MOEC, 2000; Mtahabwaa \& Rao, 2010; Oketch \& Rolleston, 2007; Phillips, 2013; Vavrus \& Moshi, 2009, p. 32).

The social and economic impact of SAPs in the late 1980s-1990s is well documented and each East African country subsequently experienced heightened poverty, a decline in school quality and school enrolments, low completion and retention and increases in the number of out-of-school children (Phillips, 2013; Oketch \& Rolleston, 2007; Vavrus, 2002; Woods, 2009). Some countries, however, experienced an expansion of private sector activity as well, such as in Tanzania, where the government would vacillate between registering private secondary schools when overrun by demand and strictly prohibiting registration of private schools due to equity concerns (Lassibille et al., 2000).

\subsection{A Second Wave of Universal Primary Education}

A second wave of Universal Primary Education (UPE) initiatives arose in the late 1990s and early 2000s, mainly driven by political expediency but also in response to the global call for UPE and EFA commitments. In Ethiopia, transitions in government in the 1990s came with the adoption of a new constitution and Free Primary Education (FPE) in 1994 (Bines \& Woods, 2007; Mekuria, 2009; Negash, 2006). Similarly in Uganda, 
preparation for the transition to UPE began in earnest in 1993 with subsidised (but not free) education for children to attend either public or private schools. This opened opportunities to less well-off students and sharply increased the gross enrolment rate to 58 per cent in the first year and 75 per cent in subsequent years (Altinyelken, 2010; Lincove, 2012; Nishimura et al., 2008; Oketch \& Rolleston, 2007; Zuze \& Leibbrandt, 2011). All official fees were then abolished in 2003, which further increased enrolments (Lincove, 2012; Moshman, 2015). Rwanda, however, underwent severe shocks during this period culminating in the post-genocide reconstruction period (1994-present) (Kabayiza, 2011; Moshman, 2015; Obura, 2003; Obura \& Bird, 2009). To increase participation, the government embarked on an ambitious reform agenda, making education free and compulsory in 2003. Rwanda's basket of reforms over this period to 2011 generated a significant increase in enrolment and completion rates and led to significant improvements in public school infrastructure, textbook distribution and class sizes (Abbot et al., 2015; ICAI, 2012; JICA, 2012; MINEDUC, 2013; Nkurunziza et al., 2012; Obura \& Bird, 2009; Schweisfurth, 2006; Upper Quartile \& IPAR - RWANDA, 2014; IBRD \& World Bank, 2011).

Similarly, Kenya and Tanzania underwent processes of expansion in the early 2000s. While most reforms in these two cases resulted in positive change, they were, however, introduced into contexts structurally ill-prepared to accommodate them. In many instances, UPE interventions led to congested classrooms, insufficient learning materials, inadequate teacher training, irrelevant curricula, and overstretched teachers and staff, all of which contributed to an overall decline in education quality (Abuya et al., 2015; Alcott \& Rose, 2016; Anangisye, 2010; Barrera-Osorio \& Zable, 2009; Baum \& Cilliers, 2018; Edwards et al., 2015; Nishimura \& Yamano, 2008; Ohba, 2013; Oketch \& Rolleston, 2007; Oketch et al., 2012a; Phillips, 2013). As a result, learning outcomes in subsequent years in these two countries plummeted, resulting in what is now commonly termed "the learning crisis" (Srivastava, 2017; World Bank, 2018b). Additionally, in Uganda, Kenya and Tanzania, there was later a push to expand access to secondary education, though with varying levels of success due to the continuing barriers to access (Ohba, 2011; Oketch et al., 2012b; UNESCO, 2012). 


\section{THE EXPANSION OF PRIVATE EDUCATION MECHANISMS IN EAST AFRICA}

Non-State actors have played a significant role in education provision in East Africa since the colonial period and as the following sections will show, their expansion may be indicative that growing education privatisation is likely underway. There are various forms of privatisation as outlined by Tooley \& Dixon (2006): open or demand-side privatisation involves the provision of State incentives such as tax credits, grants, subsidies, vouchers or other financial resources to private education providers. These subsidies are often attached to conditions such as quotas for marginalised groups or the meeting of learning targets at the school level. Supply side privatisation on the other hand, is the State intentionally instituting reforms to incorporate private actors in the provision of education services. These two forms are often viewed as being "acceptable", especially when situated within strong regulatory environments. Conversely, de facto privatisation occurs in the context of a State that has abdicated its obligation to provide quality, free education to its children. Some, however, argue that de facto privatisation has played an essential role in meeting UPE in the region and that it can be adapted to benefit all students. Additional arguments state that the model proves useful for targeting marginalised populations and providing additional revenue to the State, which could then be directed to expanding education supply (Bellei \& Orellana, 2014; Oketch, et al., 2010a; Tooley \& Dixon, 2006). However, evidence also shows that this approach favours the privileged and leads to widening inequality (Srivastava, 2010).

Given the paucity of evidence, this review does not make any conclusive determination as to which form of privatisation may be unfolding. Instead it will explore emerging trends and discuss the concurrent rise of private education provision in the region. More specifically, the review focuses on two key mechanisms: low-fee private schools (LFPS), ${ }^{2}$ including their commercial formulations, and education public-private partnerships (PPPs). For this review "private schools" will denote "formal schools that are not public, and [that] may be founded, owned, managed and financed by actors other than the State, even in cases when the State provides most of the funding and has considerable control over

2 Also referred to as low cost private schools (LCPS) or private schools for the poor. 
Table 8.1 Types of private education mechanisms in East African countries

\begin{tabular}{|c|c|c|c|c|c|c|}
\hline Form & Ethiopia & Kenya & Rwanda & Tanzania & Uganda & $\begin{array}{l}\text { South } \\
\text { Sudan }\end{array}$ \\
\hline Elite private schools (for-profit) & $\checkmark$ & $\checkmark$ & $\checkmark$ & $\checkmark$ & $\checkmark$ & $\checkmark$ \\
\hline Commercial LFPS & $\mathrm{X}$ & $\checkmark$ & $\mathrm{X}$ & $?$ & $\checkmark$ & $\checkmark$ \\
\hline Non-profit LFPS & $\checkmark$ & $\checkmark$ & $\mathrm{X}$ & $\checkmark$ & $\checkmark$ & $?$ \\
\hline PPP schools ${ }^{\mathrm{a}}$ & $\mathrm{X}$ & $?$ & $?$ & $\mathrm{x}$ & $\checkmark$ & $?$ \\
\hline $\begin{array}{l}\text { Sponsored/Government-aided } \\
\text { schools }\end{array}$ & $?$ & $\checkmark$ & $\checkmark$ & $\checkmark$ & $\checkmark$ & $\mathrm{X}$ \\
\hline Vouchers & $\mathrm{X}$ & $\checkmark$ & $?$ & $\checkmark$ & $\checkmark$ & $?$ \\
\hline $\begin{array}{l}\text { Non-profit/Philanthropic } \\
\text { (Non-governmental } \\
\text { organisations/Faith-based } \\
\text { Organisations) }\end{array}$ & $\checkmark$ & $\checkmark$ & $\checkmark$ & $\checkmark$ & $\checkmark$ & $\checkmark$ \\
\hline Community Schools ${ }^{\mathrm{b}}$ & $\checkmark$ & $\checkmark$ & $?$ & $\checkmark$ & $\checkmark$ & $\mathrm{X}$ \\
\hline $\begin{array}{l}{ }^{a} \text { Modelled after the Charter Sch } \\
\text { as the majority of these schools } \\
\text { Key: } \checkmark=\text { Present } X=\text { Absent }\end{array}$ & $\begin{array}{l}\text { ould still b } \\
\text { o available }\end{array}$ & $\begin{array}{l}\text { Communi } \\
\text { categorise } \\
\text { documenta }\end{array}$ & $\begin{array}{l}\text { y schools } \\
\text { as LFPs. } \\
\text { tion ?= Unc }\end{array}$ & $\begin{array}{l}\text { ere not cons } \\
\text { ear. }\end{array}$ & dered indep & endently \\
\hline
\end{tabular}

these schools' teachers, curriculum, and accreditation" (Lewin \& Sayed, 2005, p. 11) An overview of the most common private delivery types is presented in Table 8.1.

\subsection{Low-fee Private Schools}

LFPS are "independently funded through comparatively lower tuition fees (relative to elite or higher-fee private schools), financially sustained through direct payments from poorer or relatively disadvantaged households (though not necessarily the poorest or most disadvantaged), and independently managed and owned by a single owner or team" (Srivastava, 2013b, pp. 11-12 in Edwards et al., 2015, p. 6). LFPS can take a variety of forms, and may be operated by individuals, community and self-help groups or large commercial enterprises (Barrera-Osorio \& Zable, 2009; Srivastava \& Read, 2019).

LFPS in East Africa tend to be deeply embedded in low-income communities, providing education in constrained environments characterised by unique challenges such as: pervasive poverty; food insecurity; 
physical insecurity; high population density; muddled land use and land tenure insecurity; pollution; inadequate water supply and sanitation; a high concentration of needy or orphaned children; and insufficient social amenities and public facilities. The LFPS are therefore often small in size, housed in rented, semi-permanent buildings and rely on parental contributions or the owner's private finances. Tuition fees at these establishments typically cost between $\$ 3$ and $\$ 6$ per month, though other school-related expenditures may raise the total cost to over $\$ 30$ in some cases. These schools therefore serve children from somewhat poor (but not the poorest) households in informal settlements (Allavida Kenya, 2012; Edwards et al., 2015; Ohba, 2013).

Kenya presents perhaps a more evolved case of the presence of LPFS in the education space. In Kenya, basic education institutions are divided into two distinct categories according to the Basic Education Act 9 (2013): public and private schools (Government of Kenya, 2013). LFPS were initially considered to be "non-formal schools" which provided formal education services to out-of-school children, youth and adults. After several attempts to integrate non-formal schools into the formal education system, a further category of school was introduced (though not grafted into the Act) in 2009 (MoE, 2009; Urban Primary Education Advocacy Initiative, 2007). Most registered LFPS are now commonly referred to as "APBET schools" in reference to The Alternative Provision of Basic Education and Training (APBET) (2009) policy, which defines them as "institutions that resemble formal schools in that they aim at transmitting a formalized curriculum leading to formal school examinations. They however differ in school practices, management, financing, staffing conditions, registration, operating environment and school structures" (MoE, 2009, p. 8). The policy's rationale was that APBET schools could not meet standard registration criteria in the short term, given their constrained environment (informal settlements in designated urban areas or in arid and semi-arid areas) and the target populations they serve. Thus standards would be relaxed to accommodate them.

The APBET policy and guidelines were essentially an acknowledgement of the role that LFPS had played in accommodating children the public education system could not. In theory, APBET schools would be a stop-gap measure. However, on the ground sentiment differs and is more aligned to the view that these institutions are here to stay given the continued insufficient and ineffective investment in public education. LFPS in Kenya are now increasingly recognised as legitimate service providers of education, despite over 60 per cent of them remaining unreg- 
istered and unregulated (Allavida Kenya, 2012; Urban Primary Education Advocacy Initiative, 2007). In Kenya, the government not only registers these schools but also advanced them instructional materials and other grants between 2004 and 2017 (Edwards et al., 2015). Some studies also show that parents in informal settlements are increasingly opting to enrol their children in these institutions given growing negative perceptions of public schools. Between this, excess demand and public school constraints, evidence shows that over 50 per cent of children attend LFPS in low-income settlements (Oketch et al., 2012a; Zuilkowski et al., 2018).

Capitalising on parental desire for private schooling, corporate chains of schools have emerged in Uganda, Tanzania and Kenya. The largest and most well-known of these is Bridge International Academies (BIA), which started in Kenya before expanding to Uganda and West Africa (Rangan \& Lee, 2010). Various civil society actors have, however, raised serious concerns around the operation of this particular chain (Civil Society, 2017; EACHRights, 2018). Save for BIA, these large chains of schools remain rare throughout the region. For instance, in Uganda, 91 per cent of all LFPS were found to be either sole proprietorships or partnerships and that approximately only 15 per cent of LFPS operated as chains, the majority of which consisted of not more than two schools (CapPlus, 2017b).

\subsection{Public-Private Partnerships}

There appears to be a growing acceptance of PPPs within the region, with Kenya, Uganda Tanzania and Rwanda having put in place regulations or guidelines concerning the provision of public services via PPPs (Ndandiko \& Ibanda, 2010; United Republic of Tanzania, 2009). Ethiopia's Education Development Roadmap for 2018-2030, for instance, states that it will be setting out to increase education PPPs (ePPPs) and will provide incentives such as tax exemption, subsidies and land to private actors (MoE, 2018). The most prevalent form of ePPPs within the region, are "vouchers, subsidies, private management/contract schools and private finance initiatives" (Aslam et al., 2017, p. vi) and sponsored or government-aided schools in Kenya, Uganda and Rwanda.

In regard to school vouchers, Kenya announced plans for a voucher programme in its National Vision 2030 plan (Republic of Kenya, 2007; Vision 2030 Delivery Secretariat, 2018). Similar programmes are found in Tanzania through the National Education Trust Fund (Nafula et al., 2007). However, there is limited documentation about the implemen- 
tation or impact of these programmes in either case. Overall, countries do not appear to have significantly adopted ePPP arrangements save for Uganda, where interventions are more advanced; Uganda's school voucher programme was established in 2007 as part of its Universal Secondary Education initiative given the high demand for secondary education (Bous, 2019; ISER, 2016). While, some positive effects were found, these were not broadly shared across all PPP schools: for the majority of schools the impact of the model on learning outcomes remained inconclusive (Aslam et al., 2017; Barrera-Osorio et al., 2015; Baum, 2018; Brans, 2011; ISER 2016; Romero et al., 2017). Concerns were also raised over the State's limited capacity to monitor and regulate the situation, as well as the unequal or differential access to education for children from vulnerable groups and the poorest households caused by the intervention (Arinaitwe et al., 2019; ISER, 2016; Verger, 2012).

\subsection{The Growth of Private Schools}

While various actors exist within the education ecosystem, it is also important to assess their growth and spread. Evidence from Kenya, Tanzania and Uganda shows a greater increase in private schools relative to their public counterparts. According to one report, in Kenya " 54 per cent of the growth in enrolment between 2003 and 2007 was attributable to private schooling" (NAO, 2010, p. 19). The substantial increase in the number of unregistered LFPS, particularly in informal settlements, is furthermore largely unaccounted for (Barrera-Osorio \& Zable, 2009; GI-ESCR \& Hakijamii, 2015; KNBS, 2019; Nishimura \& Yamano, 2008; Oketch et al., 2012a; Oketch, et al., 2010a). Figure 8.1 shows the annual percentage increase by public and registered private schools for both primary and secondary levels, highlighting the increasing trend.

Over a six-year period, the number of public primary and secondary schools increased 19 per cent and 72 per cent, respectively, while the number of private schools increased by 114 per cent in primary and 63 per cent in secondary. Private primary schools have shown a larger overall growth rate, while growth in public secondary schools has slowed as private secondary school growth has increased (KNBS, 2019).

Similarly, between 1990 and 2007, Uganda increased the privatisation of social services including creating an increasing role for the private sector at all education levels (Uwezo, 2015). Until recently, government primary schools in Uganda remained the most highly utilised. However, by $2013,1.4$ million primary school students were reported to be enrolled 


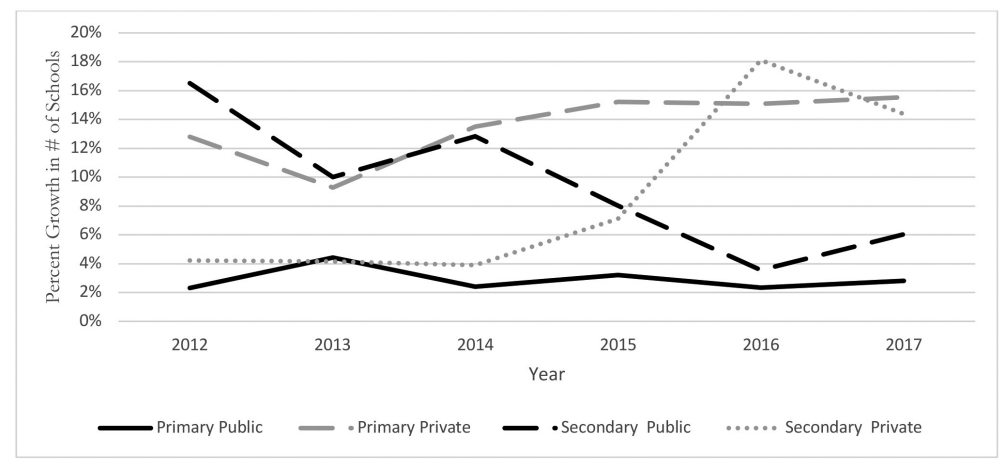

Source: Developed based on data from KNBS (2016) and KNBS (2018).

Figure 8.1 Percentage increase in private school growth in Kenya, by year (compared to previous year)

in private schools (Lincove, 2012; Riep \& Machacek, 2016; UBOS, 2014). Other reports refer to the intensification of private provision between 2005-2009, describing the private sector as constituting 59 per cent of all schools more so in urban areas (UBOS, 2014, 2019; World Bank, 2018a). In Kampala for instance, 84 per cent of school-going children receive a private education (CapPlus, 2017b).

Comparatively, Tanzania experienced a surge in both public and private schools over the last two decades: for primary schools, a surge in private providers followed the lifting of the ban on private primary schools in 1995 (CapPlus, 2017a). Between 1997 and 1999, private secondary schools enrolled slightly over half of the total secondary school student population at the time (Lassibille et al., 2000; Baum \& Cilliers, 2018). Recent figures indicate that over a ten-year period (2007-2017), there was an approximate 7 per cent increase in the number of public primary schools compared to a 275 per cent increase in private primary institutions (Baum \& Cilliers, 2018; Ministry of Finance and Planning, 2018; National Bureau of Statistics, 2016; PPMORAL, 2014). Despite this steep increase, the majority of enrolments remain in public sector schools (Baum \& Cilliers, 2018; CapPlus, 2017a; Bosu et al., 2011). However, should private sector growth continue, then this may indicate a departure from historical trends of public sector dominance (Figure 8.2). 


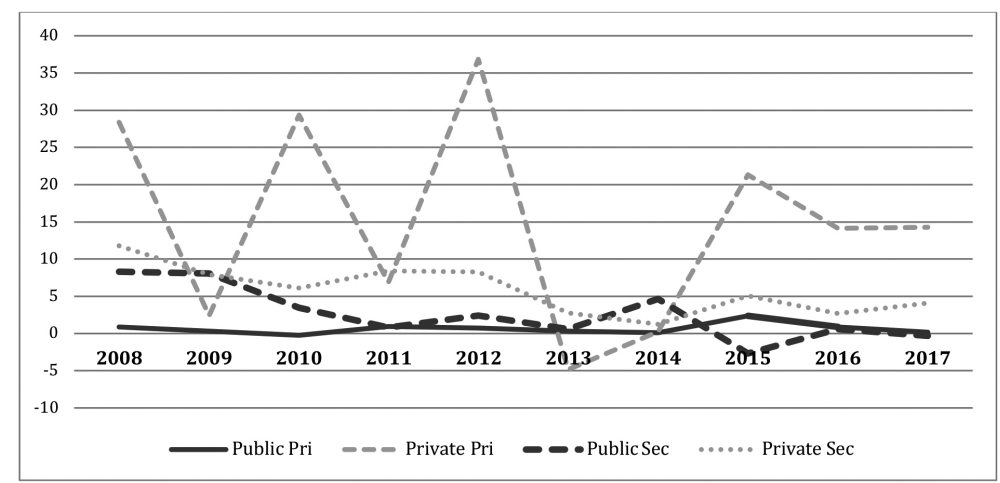

Sources: Developed based on data from Ministry of Finance and Planning (2018), National Bureau of Statistics (2016) and Baum \& Cilliers (2018).

Figure 8.2 Percentage increase in private school growth in Tanzania, by year (compared to previous year)

Developments in Ethiopia and Rwanda differ with the State remaining the largest provider of education services in both cases. Thus they were not explored any further.

\section{FACTORS DRIVING THE GROWTH OF PRIVATE EDUCATION}

Wilson-Strydoma and Okkolin (2016) have noted with concern the tendency to outline barriers to access and quality in education without having an accompanying discussion around what drives these trends in developing country contexts. In Kenya for instance, private school expansion was observed in four distinct periods, triggered by: population growth in the 1990s; the introduction of cost-sharing policies; the introduction of FPE in 2003 and its resultant access shocks; and a subsequent increase between 2006 and 2010 in response to the growing demand for alternatives to public education (Allavida Kenya, 2012; Bold et al., 2013; Edwards et al., 2015; GI-ESCR \& Hakijamii, 2015; Oketch et al., 2012a). This section provides further insights into the factors driving private sector expansion in the East Africa region. 


\subsection{Barriers to Accessing Public Institutions}

A key factor that contributes to the increase in private schools is the scarcity of government schools. In Kenya, this, coupled with public schools situated at the periphery of low-income settlements, limits accessibility especially for younger children (GI-ESCR \& Hakijamii, 2015; KNHCR, n.d.; Ohba, 2013; Oketch \& Rolleston, 2007). Conversely, LFPS and APBET schools are situated much closer to the children's home. As another example, Tanzania currently requires that all children receive a minimum of one year of pre-primary education to gain admission into public primary schools. The State does not provide early childhood education and therefore this policy has been accompanied by a proliferation of private pre-primary schools (CapPlus, 2017a). Access to public education programmes is further hampered by additional school-related costs or illegal levies charged at public schools. In many instances these payments are mandatory, leading to children being excluded from school for failing to pay (Areba et al., 2013; KNHCR, n.d.; Njihia et al., 2014; Vavrus \& Moshi, 2009). Modes of payment in public schools are also considered less flexible compared to LFPS/APBET schools in Kenya. As such, parents from low-income areas who prefer paying in instalments opt out of the public schools (Kaffenberger et al., 2018: Zollmann \& Wanjala, 2016; Zuilkowski et al., 2018).

\subsection{Declining Quality}

It is popularly suggested that the actual and perceived decline in the quality of public education is the main driver of the growth of private schools within the region. Following the implementation of FPE, various studies in Kenya, Uganda, Tanzania and Rwanda noted that, while access had expanded, learning outcomes were dropping in parallel, despite significant investments in expansion (DPG, 2009; Grogan, 2006; ICAI, 2012; ITAD, 2013; Njihia et al., 2014; Upper Quartile \& IPAR - Rwanda, 2014; Uwezo, 2015; Zuilkowski et al., 2018). Various reasons for this have been put forward: Across the region, FPE was often introduced on a political platform, with swift implementation and little corresponding institutional strengthening or planned capacity expansion (Abuya et al., 2015; Oketch \& Rolleston, 2007; Zuze \& Leibbrandt, 2011). For example, in Kenya, the introduction of FPE was announced just one month before the start of the new school term, with limited or no teacher orientation or infrastructure in place (Abuya et al., 2015; Nishimura 
\& Yamano, 2008; Oketch \& Rolleston, 2007). Similarly, in Tanzania the State issued directives in 2006 that required each ward to construct a lower secondary school to expand access. No funding accompanied this directive and, as such, ward officials adapted by imposing a contribution of $\$ 24$ on each community member for public school construction. Ward officials also converted primary schools into secondary schools and created unaccredited training programmes to increase the number of secondary school teachers, evidence of a clear disconnect between political expectations and the capacity to deliver on these demands (Languille, 2014; Phillips, 2013; Sumra \& Rajani, 2006; Zuze \& Leibbrandt, 2011).

In Uganda, enrolments increased to 171 per cent against a 41 per cent concomitant increase in both schools and teachers between 2000 and 2007 (Chapman et al., 2010). Government schools had a higher pupil-teacher ratio, reaching 72:1 compared to an average of 33:1 in private primary schools (Uwezo, 2015). Rural areas also suffered an acute shortage of qualified teachers, with existing teachers expressing a lack of "confidence" in their knowledge and capacity to implement policy directives (Chapman et al., 2010; Oketch \& Rolleston, 2007; UBOS, 2013; Wane \& Martin, 2013; Zuze \& Leibbrandt, 2011). At the same time, the Ugandan government embarked on a series of reforms, including decentralisation, implementation of a local language policy and other curriculum reforms, that led to implementation difficulties at the school level (Altinyelken, 2010; Altinyelken et al., 2014; Lincove, 2012; Nishimura et al., 2008; Oketch \& Rolleston, 2007; Penny et al., 2008; UBOS, 2013; Uwezo, 2015). The resulting decline in quality, both real and perceived, meant more parents abandoning the government sector.

Declining foreign budget support, increasing debt and austerity, and corruption further constrain education budgets, which impacts education quality (Altinyelken, 2010; Bines \&Woods, 2007; Lassibille et al., 2000; MOEC, 2000; Nishimura et al., 2008; Obura \& Bird, 2009; Oketch \& Rolleston, 2007; Srivastava, 2010; TI - Kenya, 2010; Uwezo, 2015; Vavrus \& Moshi, 2009; Weaver, 2011; Williams et al., 2015).

\subsection{Policy Orientation}

Policy orientation also plays a critical role in catalysing the growth of private actors: All countries in the East African region exhibit an openness to greater private investment in education. Ethiopia exhibits a pre-disposition for PPPs in their Education Development Roadmap (2018-2030) (MoE, 2018). In Uganda, development plans such as 
the Education Sector Strategic Plans (ESSP) and Education Strategic Investment Plans orient towards partnering with the private sector (Härmä \& Pikholz. 2017; ISER, 2016; Penny et al., 2008; Republic of Uganda, 2014; Riep \& Machacek, 2016). The vision of the Private Schools and Institutions department within Uganda's Ministry of Education and Sports (MoES) is to "foster Public Private Partnership[s] in the provision of quality education and sports" (MoES, 2020). In Rwanda policy objectives include providing an economic environment that attracts investment (Abbot et al., 2015; ICAI, 2012; Kabayiza, 2011; MoE, 2007). Rwanda's ESSP (2006-2010), outlines increased non-governmental involvement in the sector as a crucial strategy for expanding access to education, (MINEDUC, 2006, 2008). ${ }^{3}$ Furthermore, both Rwanda's first and second Economic Development and Poverty Reduction Strategies (EDPRS) create a platform for increased engagement of the private sector in education, with commitments to provide incentives (e.g. tax incentives) to non-governmental actors (IPAR, 2012; MINECOFIN, 2013; MINEDUC, 2006, 2008, 2013; IBRD \& World Bank, 2011).

The same approach appears in Tanzania's Educational Sector Development Programmes (ESDP) (1997, 2001, 2008-2017), which invite the private sector to enter partnership with the government in the construction and management of education institutions. Previously, the Education and Training Policy (1995) also considered enhanced involvement of the private sector in education as part of "broadening" the financial base for education (Vavrus, 2002). The State also provided various incentives to this effect, including "tax rebate, priority land allocation, and duty free import of school materials" (MOEC, 2000, p. 32). Similarly in Kenya, the Education Sector Support Programme (2005-2010) viewed collaboration with the private sector as a key strategy for enhancing the affordability and accessibility of education (MoEST, 2005). Positive indicators of performance in this regard were an increase in the number of private schools, the increase in enrolment of students in private secondary schools, or an increase in incentives to private actors (MoEST, 2005). 


\subsection{Weak Regulations and Weak Enforcement}

Where private education is regulated (Table 8.2), it is scarcely enforced due to lack of capacity, corruption or general inefficiency (Edwards et al., 2015; Härmä \& Pikholz, 2017). In Kenya, the closure of non-compliant LFPS is rare (Wambayi, 2004) and appears to have only intensified in the latter half of 2019 when several children lost their lives in the collapse of a school building (Daily Nation, 2019; Omar, 2019; Saturday Standard Team, 2019). Similarly, in Uganda, numerous LFPs continue to operate despite failing to meet minimum standards. There have also been challenges with enforcement due to lack of State capacity (Härmä \& Pikholz, 2017; Uwezo, 2015). Stronger calls for compliance have recently been made accompanied by threats of closure should non-compliance persist. It is unclear, however, whether the government has taken concrete action in this regard (Edwards, 2018; Museveni, 2018).

In Kenya and Uganda, weak regulations and enforcement have created opportunities for the exploitation of poor parents and teachers, with low-cost commercial private proprietors occupying regulatory gaps and loopholes in order to strengthen their market position (Bellei \& Orellana, 2014; EACHRights, 2018; EI \& KNUT, 2016). For example in Uganda, registration is a two-step process that allows proprietors to operate with a licence prior to meeting the necessary requirements. Full compliance rarely follows (CapPlus, 2017b; Härmä \& Pikholz. 2017). Additionally, weaknesses in Uganda's PPP Act (2015) include the lack of a contracting authority, lack of social impact assessments and the fact that parliament fails to play a role in the "development, approval, coordinating, monitoring, or audit process” (ISER, 2016, p. 14; Republic of Uganda, 2014).

\subsection{Donor Influence}

Donors have also contributed significantly to the growth of private actors in Africa. For instance. the UK's Department for International Development (DFID) set up the Developing Effective Private Education Nigeria (DEEPEN) project in Nigeria. In East Africa, the International Finance Corporation (IFC) plays a significant role in encouraging private participation by financing private actors and addressing the regulatory environment, with PPPs regularly included in their recommended policy package (Hall, 2015; Mundy \& Menashy, 2012). The IFC have also financed commercial chains of low-cost private schools in Kenya, such as the BIA (Baker \& Smith, 2017). The Africa Schools Program, estab- 


\section{Table 8.2 Policies and regulations concerning private actors}

\begin{tabular}{|c|c|}
\hline Ethiopia & $\begin{array}{l}\text { The Ministry of Education and Fine Arts provides guidelines on the regulation and } \\
\text { operation of non-State schools. These guidelines have been updated in the Licensing and } \\
\text { Supervision of Private Educational Institutions guidelines (Seboka, 2003:12). }\end{array}$ \\
\hline Kenya & $\begin{array}{l}\text { - Basic Education Act (2013): The Act provides for the recognition of both formal and } \\
\text { non-formal institutions. In section 49, it further stipulates minimum requirements for } \\
\text { the establishment of private schools in regard to registration and minimum standards. } \\
\text { - Alternative Provision of Basic Education and Training (APBET) Policy (2009): } \\
\text { In order to address gaps in State provision, the government allowed community or } \\
\text { non-governmental organisation (NGO) led, not-for-profit, non-formal institutions to } \\
\text { formally register as education institutions. The policy is operationalised through the } \\
\text { APBET Guidelines (2016) which cover the basic education registration requirements } \\
\text { and procedure for registration of APBET schools. }\end{array}$ \\
\hline Tanzania & $\begin{array}{l}\text { National Education Act No. 25, 1978: The Act outlines the procedures required for the } \\
\text { registration and licensing of teachers and private schools. }\end{array}$ \\
\hline Uganda & $\begin{array}{l}\text { - Education (Pre-Primary, Primary and Post-Primary) Act (2008): Section } 31 \text { outlines } \\
\text { requirements for private school registration and licensing and minimum standards for } \\
\text { all private providers. } \\
\text { - Guidelines For Establishing, Licensing, Registering and Classification of Private } \\
\text { Schools/Institutions in Uganda (2013): The guidelines describe private actors as } \\
\text { partners in national development and provide an overview of roles and responsibilities, } \\
\text { punishable offences, "procedures, requirements, standards, classification and regula- } \\
\text { tion for establishing and running private schools/institutions" (MoES, 2013, p. 4). The } \\
\text { guidelines also allow for the creation of a private school register and the capturing of } \\
\text { school data by the Ministry (MoES, 2013). } \\
\text { - Draft Guidelines for Universal Post Primary Education and Training and Universal } \\
\text { Post O-level Education and Training or PPP Schools: These non-binding guidelines } \\
\text { focus on selection criteria, implementation modalities, funding conditions, and grant } \\
\text { management (ISER, 2016). }\end{array}$ \\
\hline
\end{tabular}

lished in 2007, saw the IFC invest upwards of US\$50 million in credit guarantees that would facilitate local financing and provide advisory services to at least 500 private schools across Africa (IFC, 2007). Based on the supposed successes of pilots in Kenya and Ghana, the programme was subsequently rolled out across the region. Various other investors, private sector investment arms such as Novastar Ventures, and international financial institutions continue to focus their efforts on private sector expansion in the region (GI-ESCR, n.d; Global Justice Now \& NEU, 2019). 


\section{IMPLICATIONS OF PRIVATE SECTOR GROWTH}

Evidence is growing around the impact of the growth of private actors on equity, access, quality, transparency and participation (Aubry \& Dorsi, 2016). In the region, impact on the first three dimensions is more evident with a few key examples provided below.

\subsection{Quality}

As private schools, and in particular LFPS increase, we should consider that LFPS are often limited in the quality of their offering given their modest resources (Allavida Kenya, 2012; Edwards et al., 2015; EI \& KNUT, 2016). Income from tuition fees in LFPS is regularly insufficient for meeting expenses or needs, as a substantial number of parents are unable to consistently pay fees (Edwards et al., 2015). High mobility and teacher attrition are also common, which is understandable given that teachers working in LFPS often earn only 20-30 per cent of what government staff earn, or less (Barrera-Osorio \& Zable, 2009; Ohba, 2013; Tooley \& Dixon, 2006). Urwick and Kisa (2014) also report an increase of teacher mobility in Uganda, with increased competition for teachers between private schools and increased moonlighting behaviour by teachers in order to enhance their pay. All these factors have significant implications for the quality of education offered. Despite this, parents from low-income communities are still "opting" to take their children to private over public schools in both Kenya and Uganda, which means more and more children exposed to sub-standard education (Oketch et al., 2010a; UBOS, 2014; Zuilkowski et al., 2018).

Second, research shows that commercial education targeting low-income communities also has limits to the quality of education that is offered due in part to the primary focus being on exploiting market opportunity. For instance, evidence shows that commercial chains use cost-cutting strategies such as: employing untrained and unqualified teachers; paying low teacher salaries; remaining unregistered; providing sub-standard facilities; ineffective teaching methods; expulsion of poorer children; selecting out poor performers; and in some cases curtailing parental participation (Edwards et al., 2015; EI \& KNUT, 2016; Oketch et al., 2012a; Riep \& Machacek, 2016; Romero \& Sandefur, 2019; Romero et al., 2017). 


\subsection{Learning Outcomes}

There has been significant debate in the past over which type of school is able to deliver the desired learning outcomes. This discussion has centred mainly on academic outcomes, for which the evidence remains inconclusive at best, especially when confounding factors are taken into account (Edwards et al., 2015; Ohba, 2013). For example, some assessments suggest that public education is poor and that private schools outperform public schools (Anangisye, 2010; Languille, 2014; Uwezo, 2015; Woods, 2009) while others show that public schools may perform better and provide greater value than private schools (Alcott \& Rose, 2016; Grogan, 2006; Lassibille et al., 2000; MOEC, 2000). Thus, as private education expands, the value for money question still remains.

\subsection{Widening Stratification and Inequality}

While the increase in LFPS is recognised for expanding the availability of schools, they are usually out of reach of the poorest children (Edwards et al., 2015; Oketch, et al., 2010a;). Fees in LFPS can cost between 4.7-8.1 per cent of a household's income per month, per child, which is not feasible for families with more than one child and who regularly experience negative budgets. The financial burden increases when families take out loans and digital credit to finance their child's education (Donovan \& Park, 2019; Kaffenberger et al., 2018; EI \& KNUT, 2016; Mutisya, 2018; Zollmann \& Wanjala, 2016). In Kenya and Uganda, parental inability to consistently pay fees has led to pupils in LFPS being implicitly categorised according to a "differentiated scale of payment" such as "those who pay in full, those who do not pay at all and those who pay partial fees" (Edwards et al., 2015: 25; Mbole \& Kimathi, 2019). This introduces "micro-segregation" even amongst the poor, further exacerbating inequalities (Allavida Kenya, 2012; Barrera-Osorio \& Zable, 2009; Riep \& Machacek, 2016; Vavrus, 2000; Zuze \& Leibbrandt, 2011, pp. 170-171).

Alcott and Rose (2016) also demonstrate that private schools do very little to narrow inequalities in learning, especially for the most disadvantaged in Kenya and in Tanzania. Inequity is further reinforced by narrow selection criteria that place education out of the reach of children who are considered more expensive to educate, such as children with disabilities or those who may have low academic potential (Allavida Kenya, 2012; Edwards et al., 2015; GI-ESCR \& Hakijamii, 2015; Lassibille et al., 2000; Oketch, et al., 2010a). In countries like Kenya, the APBET policy 
has created a parallel, lower quality tier of education without any clear resolution to fix underlying problems. This is likely to generate further inequalities in the long term, especially given that the necessary checks and balances are lacking (Alcott \& Rose, 2016; Edwards et al., 2015). Inequalities in education have been known to reproduce economic, social and political and knowledge inequalities (ISSC, IDS, \& UNESCO, 2016). Therefore the expansion of private actors or latent privatisation may work to make children within East Africa's low-income settlements even more vulnerable to suffering these effects.

\section{CONCLUSION}

While various achievements have been made across the region, public education systems are beset by a range of systemic challenges. As such, East African countries continue to struggle to deliver on the right to education for all citizens. The increase in private actors in education is symptomatic of this struggle. The impact of this increase is, however, not extensively documented, though a nascent body of working is now emerging. What we can however conclude is that effects of privatisation observed in other parts of the world, as outlined in Adamson et al. (2016), are now part of the East African experience. The increase in private actors and its resultant impact is, however, largely absent from policy discourse despite the growing evidence. East African States remain fairly receptive to private participation in the education sector. This chapter will therefore hopefully encourage East African governments and education stakeholders to further interrogate the evidence and to invest in the systematic production of valid, reliable, objective and up-to-date evidence in this regard. The data vacuum must be addressed across the region, especially where non-formal and low-cost private schools are concerned. Better monitoring of the state, scale, scope, and impact of the private sector would go a long way to enhancing State and private actor accountability.

Lastly, this chapter has demonstrated how growth in private provision is largely driven by challenges in the public sector. There is, however, a cyclical nature to the policy mistakes that have been made, especially in the haphazard rolling out of education reforms, which has affected the quality of education and learning outcomes. It is therefore hoped that, as governments across the region set into motion their respective curriculum reform programmes, they will be able to reflect and grow from past missteps. 


\section{REFERENCES}

Abbot, P., Sapsford, R., \& Rwirahira, J. (2015). Rwanda's potential to achieve the millennium development goals for education. International Journal of Educational Development, 40, 117-125.

Abuya, B. A., Onsomu, E. O., \& Moore, D. (2014). Determinants of educational exclusion: Poor urban girls' experiences in- and out-of-school in Kenya. Prospects, 44(3), 381-394.

Abuya, B. A., Admassu, K., Ngware, M., Onsomu, E. O., \& Oketch, M. (2015). Free primary education and implementation in Kenya: The role of primary school teachers in addressing the policy gap. SAGE Open (January-March), $1-10$.

Adamson, F., Åstrand, B., \& Darling-Hammond, L. (Eds.). (2016). Global Education Reform: How Privatization and Public Investment Influence Education Outcomes. New York: Routledge, Taylor \& Francis.

Alcott, B., \& Rose, P. (2016). Does private schooling narrow wealth inequalities in learning outcomes? Evidence from East Africa. Oxford Review of Education, 42(5), 495-510.

Allavida Kenya. (2012). Access to and Quality Basic Education in Kibera, Nairobi. Retrieved from: http:/www.uwezo.net/wp-content/uploads/2013/01/ KE_COMM_Networks_AllavidaReport.pdf

Altinyelken, H. K. (2010). Curriculum change in Uganda: Teacher perspectives on the new thematic curriculum. International Journal of Educational Development, 30(2), 151-161.

Altinyelken, H. K., Moorcroft, S., \& Van der Draai, H. (2014). The dilemmas and complexities of implementing language-in-education policies: Perspectives from urban and rural contexts in Uganda. International Journal of Educational Development, 36, 90-99.

Anangisye, W. L. (2010). Revisiting the alternative responses to the perceived quality "decline" in basic education in Tanzania. KEDI Journal of Educational Policy, 7(1), 115-138.

Areba, N. G., Ondimm, P. C., Monga're, E., \& Zablon, N. O. (2013). The hidden costs of free primary education and their implication on enrolment in Kisii Central District, Kenya. Journal of Education and Practice, 4(18), 97-106.

Arinaitwe, J. M., Taylor, N., Broadbent, E., \& Oloya, C. (2019, March). Secondary Education in Sub-Saharan Africa Teacher Preparation and Support Case Study: Uganda. MasterCard Foundation. Retrieved from: https:// mastercardfdn.org/wp-content/uploads/2019/07/SEA-Teacher-Preparation -and-Support-Case-Study-Uganda.pdf

Aslam, M., Rawal, S., \& Saeed, S. (2017). Public-Private Partnerships in Education in Developing Countries: A Rigorous Review of the Evidence. Ark Education Partnerships Group. Retrieved from: http://arkonline.org/sites/ default/files/Ark_EPG_PPP_report.pdf

Aubry, S., \& Dorsi, D. (2016). Towards a human rights framework to advance the debate on the role of private actors in education. Oxford Review of Education, 42(5), 612-628. 
Baker, T., \& Smith, W. (2017). From Free to Fee: Are For-profit, Fee Charging Private Schools the Solution for World's Poor? RESULTS Educational Fund. Retrieved from: http:/www.results.org/uploads/files/From_Free to_Fee.pdf

Barrera-Osorio, F., \& Zable, I. (2009). Private School Support Program: A Characterization of the Private Segment of Kenya's Educational Sector. Retrieved from: http://siteresources.worldbank.org/EDUCATION/Resources/ 278200-1126210664195/1636971-1238439091031/Kenya_Baseline description_June09.pdf

Barrera-Osorio, F., De Galbert P., Habyarimana, J., \& Sabarwal, S. (2015). The Impact of Public-Private Partnerships on School Performance: Evidence from a Randomized Controlled Trial in Uganda. World Bank Policy Research Working Paper No. 7905. Retrieved from: http://documents.worldbank.org/ curated/en/470851480966927631/pdf/WPS7905.pdf

Baum, D. R. (2018). Private School Vouchers in Developing Countries: A Survey of the Evidence. Retrieved from: https:/osf.io/preprints/socarxiv/6j7qp/ download

Baum, D. R., \& Cilliers, J. (2018). Private school vouchers for expanding secondary school access? The case of Tanzania. International Journal of Educational Management, 32(7), 1307-1318.

Bellei, C., \& Orellana, V. (2014). What Does "Education Privatisation” Mean? Conceptual Discussion and Empirical Review of Latin American Cases. Center for Advanced Research in Education \& Sociology, Department University of Chile, ESP Working Paper Series 2014, No. 62. Retrieved from: http://www.periglobal.org/sites/periglobal.org/files/WP62\%20What\%20does $\% 20$ 'Education $\% 20$ Privatisation'\%20mean.pdf

Bines, H., \& Woods, E. (2007). Cross Country (Eritrea, Ethiopia, Rwanda and Tanzania) Case Study. Country profile prepared for the Education for All Global Monitoring Report 2008. Education for All by 2015: Will We Make It? Retrieved from: http://unesdoc.unesco.org/images/0015/001555/155508e.pdf

Bold, T., Kimenyi, M., Mwabu, G., \& Sandefur, J. (2013). Why Did Abolishing Fees Not Increase Public School Enrollment In Kenya? Africa Growth Initiative, Working Paper 4. Retrieved from: https:/www.brookings.edu/wp -content/uploads/2016/06/01-education-kenya-kimenyi.pdf

Bosu, R., Dare, A., Dachi, H., \& Fertig, M. (2011). School leadership and social justice: Evidence from Ghana and Tanzania. International Journal of Educational Development, 31, 67-77.

Bous, K. (2019). False Promises: How Delivering Education through PublicPrivate Partnerships Risks Fuelling Inequality instead of Achieving Quality Education for All. Oxford: Oxfam GB. Retrieved from: https://oxfamilibrary .openrepository.com/bitstream/handle/10546/620720/bp-world-bank -education-ppps-090419-en.pdf

Brans, B. (2011). PPPs - Public Private Partnerships in Education: Analyzing PPPs as a policy tool for Universal Secondary Education in Uganda. Amsterdam, Netherlands: Universiteit van Amsterdam. Retrieved from: https://educationanddevelopment.files.wordpress.com/2008/04/ppps-in -uganda-bo-joe-brans.pdf 
CapPlus. (2017a). Banking on Education, Dar es Salaam, Tanzania, 1 May. Retrieved from: http://capplus.org/files/2017/05/CapPlus-LCS-Market-in-Dar -es-Salaam-2017-04-26.pdf

CapPlus. (2017b). Banking on Education Kampala, Uganda, 1 May. Retrieved from: http://capplus.org/files/2016/12/Banking-on-Education-in-Kampala-05 .01.pdf

Chapman, D. W., Burton, L., \& Werner, J. (2010). Universal secondary education in Uganda: The head teachers' dilemma. International Journal of Educational Development, 30(1), 77-82.

Civil Society. (2017). 174 Organizations Worldwide Call Investors to Cease Support to American Chain of Schools Bridge International Academies. Retrieved from: http://bit.ly/2vnat0x

Daily Nation. (2019, 24 September). Blame game as 7 pupils die in classroom collapse in Kenya. The Daily Nation. Retrieved from: https:/www .theeastafrican.co.ke/news/ea/Kenya-school-classroom-collapse/4552908 -5284890-iwg2kqz/index.html

Donovan, K. P., \& Park, E. (2019, 20 September). Perpetual debt in the Silicon Savannah. Boston Review. Retrieved from: http://bostonreview.net/ class-inequality-global-justice/kevin-p-donovan-emma-park-perpetual-debt -silicon-savannah

DPG. (2009). Education Statistics Brief. Retrieved from: https://www.google $. \mathrm{com} / \mathrm{url}$ ? $\mathrm{sa}=\mathrm{t} \& \mathrm{rct}=\mathrm{j} \& \mathrm{q}=\&$ esrc $=\mathrm{s} \&$ source $=$ web $\& \mathrm{~cd}=2 \& \mathrm{cad}=\mathrm{rja} \& u a c t$ $=8 \&$ ved=0ahUKEwioq6_8rfjQAhWFVhoKHW1dC00QFggeMAE \&url=httpper cent3Aper cent2Fper cent2Fwww.tzdpg.or.tzper cent2Ffileadminper cent2F_migratedper cent2Fcontent_uploadsper cent2FTanzania_education_statistics_2009_1_.doc\&usg=AFQjCNEpi6t2U-ZmO2P8ShfiandBstqcLg\&sig2 $=$ w-TyR4tN8Fic0Dyb8Go9YQ

EACHRights. (2018). Letter of complaint submitted by the East Africa Centre for Human Rights on April 2018. Compliance Advisor Ombudsman. Retrieved from: http://www.cao-ombudsman.org/cases/document-links/documents/CA OComplaintEACHRights-16April18.pdf

Edwards, D. B., Klees, S. J., \& Wildish, J. L. (2015). Dynamics of Low-Fee Private Schools in Kenya: Governmental Legitimation, School-Community Dependence, and Resource Uncertainty. Retrieved from: http://download.ei-ie .org/Docs/WebDepot/2015_Kenya_Low-FeeSchools_final.pdf

Edwards, S. (2018, 9 February). Debate over for-profit schools in Uganda boils over as Bridge and others refuse to close. Devex. Retrieved from: https:// www.devex.com/news/debate-over-for-profit-schools-in-uganda-boils-over -as-bridge-and-others-refuse-to-close-92065

EI, \& KNUT. (2016). Bridge vs. Reality: A Study of Bridge International Academies For-profit-schooling in Kenya. Retrieved from: https://download .ei-ie.org/Docs/WebDepot/Bridge\%20vs\%20Reality_GR\%20Report.pdf

GI-ESCR. (n.d.). The Role of International Development Cooperation \& Financial Institutions. Retrieved from: https://www.gi-escr.org/private-actors -social-services/education/development-cooperation-institutions

GI-ESCR, \& Hakijamii. (2015). Kenya's Support to Privatisation in Education and its Impact on Discrimination and Segregation. Preliminary parallel 
Report submitted during the 71st session of the UN Committee on the Rights of the Child. Retrieved from: http://globalinitiative-escr.org/wp-content/ uploads/2015/09/FINAL-150907-Hakijamii_GI-ESCR-Kenya-Parallel-report -ICESCR-privatisation-right-to-education.p $\overline{d f}$

Global Justice Now, \& NEU. (2019). In Whose Interest? The UK's Role in Privatising Education around the World. Retrieved from: https://www .globaljustice.org.uk/sites/default/files/files/news_article/neu1147_for_the public_good_report_final_0.pdf

Government of Kenya. (2013). Basic Education Act, 2013, No. 14 of 2013. Retrieved from: http://planipolis.iiep.unesco.org/upload/Kenya/Keny aBasicEducationActNo_14of2013.pdf

Grogan, L. (2006). Who benefits from Universal Primary Education in Uganda? Unpublished report, Department of Economics, University of Guelph.

Hall, D. (2015). Why Public-Private-Partnerships (PPPs) Don't Work: The Many Advantages of the Public Alternative. Greenwich: Public Services International Research Unit at the University of Greenwich. Retrieved from: http://www.world-psi.org/sites/default/files/rapport_eng_56pages_a4_lr.pdf

Härmä, J., \& Pikholz, L. (2017). Low Fee Private Schools in Low-income Districts of Kampala, Uganda. Chicago: CapitalPlus Exchange Corporation.

IBRD (International Bank for Reconstruction and Development), \& The World Bank. (2011). Rwanda Education Country Status Report; Toward Quality Enhancement And Achievement Of Universal Nine Year Basic Education; An Education System in Transition; a Nation in Transition. Washington, DC: World Bank.

ICAI (Independent Commission for Aid Impact). (2012). DFID's Education Programmes in Three East African Countries, Report 10. Retrieved from: http://www.oecd.org/countries/rwanda/50360183.pdf

IFC. (2007, 15 July). IFC Supports Private Education in Africa. Washington, DC. Retrieved from: IFC: https://www.ifc.org/wps/wcm/connect/news_ext content/ifc_external_corporate_site/news+and+events/news/features_africa _private_education_jül07

Institute of Policy Analysis and Research - Rwanda (IPAR). (2012). IPAR Observatory Report: The Rwandan Education and Skills System. Kigali, Rwanda: IPAR.

ISER. (2016). A Threat or Opportunity? Public-Private Partnerships in Education in Uganda. Retrieved from: https://www.iser-uganda.org/ images/downloads/Threat_or_Opportunity_Public_Private_Partnership_in Education_in_Uganda.pdf

ISSC, IDS, \& U UNESCO. (2016). World Social Science Report 2016, Challenging Inequalities: Pathways to a Just World, Paris: UNESCO Publishing. Retrieved from: https://unesdoc.unesco.org/ark:/48223/pf0000245825

ITAD. (2013). Joint Evaluation of Budget Support to Tanzania: Lessons Learned and Recommendations for the Future. Final Report (Vol. 2). Retrieved from: http://ec.europa.eu/europeaid/how/evaluation/evaluation_reports/reports/ 2013/1321_vol2_en.pdf 
JICA. (2012). Basic Education Sector Analysis Report - Rwanda. International Development Center of Japan Inc. (IDCJ). Retrieved from: http://open jicareport.jica.go.jp/pdf/12083317.pdf

Kabayiza, B. (2011). Exploring the Collaborative Role of Government and the Catholic Church in Education Decentralization in Rwanda: A Case Study of Two Secondary Schools in Nyarugenge District (Master of Education). School of Education, University of the Witwatersrand, Johannesburg.

Kaffenberger, M., Totolo, E., \& Soursourian, M. (2018). A Digital Credit Revolution Insights from Borrowers in Kenya and Tanzania. Retrieved from: https://www.cgap.org/sites/default/files/publications/Working-Paper-A -Digital-Credit-Revolution-Oct-2018.pdf

KNBS. (2016). Economic Survey 2016. Nairobi: KNBS. Retrieved from: http:// www.knbs.or.ke/?wpdmpro=economic-survey-2016

KNBS. (2018). Economic Survey 2018. Nairobi: KNBS. Retrieved from: http:// www.knbs.or.ke/?wpdmpro=economic-survey-2018

KNBS. (2019). Economic Survey 2019. Nairobi: KNBS. Retrieved from: http:// www.knbs.or.ke/?wpdmpro=economic-survey-2019

KNHCR. (n.d.). The Fourth State of Human Rights Report Post Promulgation 2010-2014. Human Rights: The Elusive Mirage? Retrieved from: http://www .knchr.org/Portals/0/StateOfHumanRightsReports/4th\%20SHR\%20Report .pdf

Languille, S. (2014). Quality education through performativity: "Learning crisis" and technology of quantification in Tanzania. International Journal of Educational Development, 39, 49-58.

Lassibille, G., Tan, J., \& Sumra, S. (2000). Expansion of private secondary education: Lessons from recent experience in Tanzania. Comparative Education Review, 44(1), 1-28.

Lelei, M. C., \& Weidman, J. C. (2012). Education development in Kenya: Enhancing access and quality. In C. Acedo, D. Adams, \& S. Popa (Eds.), Quality and Qualities Tensions in Education Reforms (pp. 143-162). Rotterdam: Sense Publishers.

Lewin, K. M., \& Sayed Y. (2005). Non-Government secondary schooling in Sub-Saharan Africa. Exploring the evidence in South Africa and Malawi. Department for International Development: Educational Papers, 59. Centre for International Education. Retrieved from: https://assets.publishing.service .gov.uk/media/57a08c5c40f0b6497400117c/paper59.pdf

Lincove, J. A. (2012). The influence of price on school enrolment under Uganda's policy of free primary education. Economics of Education Review, 31(5), 799-811.

Lofchie, M. F. (2014). The Political Economy of Tanzania: Decline and Recovery. Philadelphia: University of Pennsylvania Press.

Mbole, F., \& Kimathi, D. (2019, 8 July). What Solutions Would Make a Difference in Education Finance? FSD Kenya. Retrieved from: https://fsdkenya.org/ blog/what-solutions-would-make-difference-in-education-finance/

Mekuria, Y. Z. (2009). The Right to Primary Education in Ethiopia: Progress, Prospects and Challenges (Master's in International Human Rights Law). University of Oslo, Norway. 
MINECOFIN. (2013). Economic Development and Poverty Reduction Strategy II. 2013-2018. Republic of Rwanda. Retrieved from: http://www.minecofin .gov.rw/fileadmin/templates/documents/NDPR/EDPRS_2.pdf

MINEDUC. (2006). Education Sector Strategic Plan 2006-2010. Republic of Rwanda. Retrieved from: http://www.rencp.org/wp-content/uploads/2010/06/ MINEDUC-Rwanda-Education-Sector-Plan-2006-2010.pdf

MINEDUC. (2008). Education Sector Strategic Plan 2008-2012. Retrieved from. http://planipolis.iiep.unesco.org/upload/Rwanda/Rwanda_ESSP_2008 -2012.pdf

MINEDUC. (2013). Education Sector Strategic Plan 2013/14-2017/18. Republic of Rwanda. Retrieved from: http://www.mineduc.gov.rw/innovation/IMG/ pdf/ESSP 2013 - 2018 Final.pdf

Ministry of Finance and Planning. (2018). Economic Survey 2017. United Republic of Tanzania. Retrieved from: http://www.mof.go.tz/docs/ ECONOMIC\%20SURVEY\%20BOOK\%202017\%20FINAL.pdf

MoE. (2007). Education Sector Strategic Plan (2008-2012). Republic of Rwanda. Retrieved from http://planipolis.iiep.unesco.org/upload/Rwanda/ Rwanda_ESSP 2008-2012.pdf

MoE. (2009). Policy for Provision of Basic Education and Training. Nairobi: Ministry of Education. Retrieved from: https://planipolis.iiep.unesco.org/ sites/planipolis/files/ressources/kenyapolicyalternativeprovisionbasiceducati ontraining.pdf

MoE. (2018). Ethiopian Education Development Roadmap (2018-30) An Integrated Executive Summary. Education Strategy Center. Retrieved from: http://planipolis.iiep.unesco.org/sites/planipolis/files/ressources/ethiopia education development roadmap 2018-2030.pdf

MŌEC. (2000). Education in a Global Era: Challenges to Equity, Opportunity for Diversity. United Republic of Tanzania. Retrieved from: http:/www .tanzania.go.tz/egov_uploads/documents/EDUCATION_IN_GLOBAL_ERA Sw.pdf

MoES. (2013). Guidelines for Establishing, Licensing, Registering and Classification of Private Schools/Institutions in Uganda. Retrieved from: https://businesslicences.go.ug/uploads/documents/Licensing\%20and $\% 20$ regGuidelines $\% 202014 \% 201$ latest $\% 20$ version-2.pdf

MoES. (2020). Private Schools and Institutions. Retrieved from: http://www .education.go.ug/private-schools-institutions/

MoEST. (2005). Kenya Education Sector Support Programme 2005-2010. Delivering Quality Education and Training to All Kenyans. Retrieved from: https://planipolis.iiep.unesco.org/sites/planipolis/files/ressources/kenya kessp final 2005.pdf

Moshman, D. (2015). Identity, history, and education in Rwanda: Reflections on the 2014 Nobel Peace Prize. Child Abuse \& Neglect, 44, 1-4.

Mtahabwaa, L., \& Rao, N. (2010). Pre-primary education in Tanzania: Observations from urban and rural classrooms. International Journal of Educational Development, 30(3), 227. 
Mtonga, H. L. (1993). Comparing the role of education in serving socioeconomic and political development in Tanzania and Cuba. Journal of Black Studies, 23(3), 382-402.

Mundy, K., \& Menashy, F. (2012). The role of the International Finance Corporation in the promotion of public private partnerships for educational development. In S. Robertson, K. Mundy, \& A. Verger (Eds.), Public Private Partnerships in Education: New Actors and Modes of Governance. Cheltenham, UK and Northampton, MA, USA: Edward Elgar Publishing.

Museveni, J. K. (2018, 15 February). Enforcement of the Standard Operating Procedure (SOP) for private schools and school charges in Uganda. New Vision. Retrieved from: https://www.newvision.co.ug/new_vision/news/ 1471272/enforcement-standard-operating-procedure-sop-private-schools -school-charges-uganda

Mutisya, J. (2018, 21 April). Two-thirds of loans taken by families are spent on food and school fees. The Daily Nation. Retrieved from: https://www.nation .co.ke/newsplex/credit/2718262-4492558-1gllj6/index.html

Nafula, N. N., Onsomu, E. N., Manda, D. K., \& Kimalu, P. K. (2007). Private Sector Investment in Primary and Secondary Education in Kenya: Issues, Challenges and Recommendations. KIPPRA Discussion Paper, No. 76. Retrieved from: http://erepository.uonbi.ac.ke:8080/xmlui/bitstream/handle/ $11295 / 46595 /$ privatesectorinvestmentinprimaryandsecondary.pdf? sequence= 1

NAO. (2010, 18 June). DFID Bilateral Support to Primary Education: Report by the Comptroller and Auditor General HC 69 Session 2010-2011. Retrieved from: https://reliefweb.int/sites/reliefweb.int/files/resources/AB A7C949DEBDEC8FC125774900581497-DFID_Bilateral_Support_jun2010 .pdf

National Bureau of Statistics. (2016). Tanzania in Figures. Dar es Salaam: United Republic of Tanzania. Retrieved from: https://de.tzembassy.go.tz/uploads/ Tanzania_in_Figures_NBS_2016.pdf

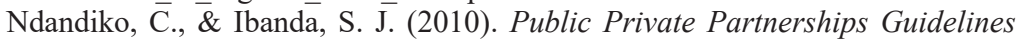 for Local Governments. MOLG and UNDP. Retrieved from: https://www .undp.org/content/dam/uganda/img/Research\%20and\%20Publications/PPP \%20Guidelines\%20Final.pdf

Negash, T. (2006). Education in Ethiopia: From Crisis to the Brink of Collapse. Discussion Paper 33. Uppsala: Nordiska Afrikainstitutet. Retrieved from: https://www.diva-portal.org/smash/get/diva2:240545/FULLTEXT02.pdf

Nishimura, M., \& Yamano, T. (2008). School choice between public and private primary schools under the free primary education policy in rural Kenya. GRIPS Policy Information Center Discussion Paper: 08-02. Retrieved from: http://www.grips.ac.jp/r-center/wp-content/uploads/08-02.pdf

Nishimura, M., Yamano, T., \& Sasaoka, Y. (2008). Impacts of the universal primary education policy on educational attainment and private costs in rural Uganda. International Journal of Educational Development, 28(2), 161-175.

Njihia, M., Nderitu, J. K., Barasa, L., \& Khayira, C. (2014). The Use and Usefulness of School Grants: Lessons from Kenya. Paris: IIEP. Retrieved from: http://unesdoc.unesco.org/images/0022/002282/228289E.pdf 
Nkurunziza, J., Broekhuis, A., \& Hooimeijer, P. (2012). Free education in Rwanda: Just one step towards reducing gender and sibling inequalities. Education Research International, (396019), 1-11.

Nyerere, J. (1967). The Arusha Declaration and TANU's Policy on Socialism and Self-reliance. Dar Es Salaam: TANU. Retrieved from: http://library.fes.de/ fulltext/bibliothek/2-tanzania-s0019634.pdf

Obura, A. (2003). Never Again: Educational Reconstruction in Rwanda. Paris: International Institute for Educational Planning, UNESCO. Retrieved from: http://unesdoc.unesco.org/images/0013/001330/133051e.pdf

Obura, A. P., \& Bird, L. (2009). Education Marginalisation in Post-Conflict Settings: A Comparison of Government and Donor Responses in Burundi and Rwanda. Background paper prepared for the Education for All Global Monitoring Report 2010, Reaching the Marginalized. Retrieved from http:// unesdoc.unesco.org/images/0018/001866/186602e.pdf

Ohba, A. (2011). The abolition of secondary school fees in Kenya: Responses by the poor. International Journal of Educational Development, 31(4), 402-408.

Ohba, A. (2013). Do low-cost private school leavers in the informal settlement have a good chance of admission to a government secondary school? A study from Kibera in Kenya. Compare: A Journal of Comparative and International Education, 43(6), 763-782.

Oketch, M., \& Rolleston, C. (2007). Policies on free primary and secondary education in East Africa: Retrospect and prospect. Review of Research in Education, 31, 131-158.

Oketch, M., Mutisya, M., \& Sagwe, J. (2012a). Do poverty dynamics explain the shift to an informal private schooling system in the wake of free public primary education in Nairobi slums? London Review of Education, 10(1), 3-17.

Oketch, M., Mutisya, M., \& Sagwe, J. (2012b). Parental aspirations for their children's educational attainment and the realisation of universal primary education (UPE) in Kenya: Evidence from slum and non-slum residences. International Journal of Educational Development, 32(6), 764-772.

Oketch, M., Mutisya, M., Ngware, M., \& Ezeh, A. C. (2010a). Why are there proportionately more poor pupils enrolled in non-state schools in urban Kenya in spite of FPE policy? International Journal of Educational Development, $30(1), 23-32$.

Oketch, M., Mutisya, M., Ngware, M., Ezeh, A. C., \& Epari, C. (2010b). Free primary education policy and pupil school mobility in urban Kenya. International Journal of Educational Research, 49, 173-183.

Omar, S. R. (2019, 23 September). Magoha appoints taskforce to investigate Precious Talent School tragedy. The Standard. Retrieved from: https:// www.standardmedia.co.ke/article/2001343036/magoha-appoints-taskforce-to -investigate-school-tragedy

Penny, A., Ward, M., Read, T., \& Bines, H. (2008). Education sector reform: The Ugandan experience. International Journal of Educational Development, 28, 268-285.

Phillips, K. D. (2013). Dividing the labor of development: Education and participation in rural Tanzania, Comparative Education Review, 57(4), 637-661. 
PPMORAL. (2014). Pre-Primary, Primary and Secondary Education Statistics, 2013. National DATA. Retrieved from: http://www.pmoralg.go .tz/noticeboard/tangazo-1023-20141229-Basic-Education-Statistics-BEST/ FINAL-NATIONAL-27-MAY-2014.pdf

Rangan, V. K., \& Lee, K. (2010). Bridge International Academies: A School in a Box. Harvard Business School, N9-511-064. Retrieved from: https://www .bridgeinternationalacademies.com/wp-content/uploads/2018/08/Case-Study -Harvard-Business-School-2010.pdf

Republic of Kenya. (2007). Kenya Vision 2030: A Globally Competitive and Prosperous Kenya. Retrieved from: https://www.researchictafrica.net/ countries/kenya/Kenya_Vision_2030__2007.pdf

Republic of Uganda. (2014). The Püblic Private Partnerships Act, 2015. Retrieved from: https://budget.go.ug/sites/default/files/Public\%20Private \%20Partnership\%20Act\%202015.pdf

Riep, C., \& Machacek, M. (2016). Schooling the Poor Profitably: The Innovations and Deprivations of Bridge International Academies in Uganda. Brussels: Education International. Retrieved from: https://download.ei-ie.org/Docs/ WebDepot/DOC_Final_28sept.pdf

Romero, M., \& Sandefur, J. (2019). Beyond Short-term Learning Gains: The Impact of Outsourcing Schools in Liberia after Three Years. Retrieved from: https://www.poverty-action.org/sites/default/files/publications/Beyond $\%$ 20Short-Term\%20Learning\%20Gains.pdf

Romero, M., Sandefur, J., \& Sandholtz, W. A. (2017). Can Outsourcing Improve Liberia's Schools? Preliminary Results from Year One of a Three-Year Randomized Evaluation of Partnership Schools for Liberia. Working Paper 462. Retrieved from: https://www.cgdev.org/sites/default/files/partnership -schools-for-liberia.pdf

Saturday Standard Team. (2019, 28 September). Classes of death: Schools crackdown to leave thousands of pupils stranded. The Standard. Retrieved from: https://www.standardmedia.co.ke/article/2001343618/crisis-in-schools -as-crackdown-begins

Schweisfurth, M. (2006). Global and cross-national influences on education in post-genocide Rwanda. Oxford Review of Education, Special Issue: Comparative Inquiry and Educational Policy Making, 32(5), 697-709.

Seboka, B. (2003). School Choice and Policy Response: A Comparative Context Between Private and Public Schools in Urban Ethiopia. Paper presented at the International Conference on African Development Studies in Ethiopia, Addis Ababa. Retrieved from: http://scholarworks.wmich.edu/africancenter icad archive $/ 59$

Somerset, A. (2007). A Preliminary Note on Kenya Primary School Enrolment Trends over Four Decades. CREATE: pathways to access series, PTAs Research monographs, 009. Consortium for Research on Educational Access, Transitions and Equity (UK), Centre for International Education. Brighton, UK: University of Sussex.

Srivastava, P. (2010). Public-private partnerships or privatisation? Questioning the state's role in education in India. Development in Practice, 20(4-5), $540-553$. 
Srivastava, P. (2017, 18 October). The World Bank's 2018 World Development Report on Education: A sceptic's review. From Poverty to Power. Retrieved from: https://oxfamblogs.org/fp2p/the-world-banks-2018-world-development -report-on-education-a-sceptics-review/

Srivastava, P., \& Read, R. (2019). Philanthropic and impact investors: Private sector engagement, hybridity and the problem of definition. In N. Y. Ridge, \& A. Terway (Eds.), Philanthropy in Education: Diverse Perspectives and Global Trends (pp. 15-36). NORRAG Series on International Education and Development. Cheltenham, UK and Northampton, MA, USA: Edward Elgar Publishing.

Sumra, S., \& Rajani, R. (2006). Secondary Education in Tanzania: Key Policy Challenges. Working Paper 06.4. HakiElimu Working Paper series. Retrieved from: http://hakielimu.org/files/publications/document34secondary_edu_tz policy_challenges_en.pdf

TI - Kenya (Transparency International - Kenya). (2010). Kenya Education Sector Integrity Study Report. Retrieved from https://tikenya.org/wp-content/ uploads/2017/06/kenya-education-sector-integrity-study-2010.pdf

Tooley, J., \& Dixon, P. (2006). De facto privatisation of education and the poor: Implications of a study from sub-Saharan Africa and India. Compare: A Journal of Comparative and International Education, 36(4), 443-462.

UBOS. (2013). Uganda National Panel Survey 2010/2011 Wave II Report. Kampala, Uganda: Uganda Bureau Of Statistics.

UBOS. (2014). Uganda National Household Survey 2012/2013. Kampala, Uganda: Uganda Bureau Of Statistics. Retrieved from: http://www.ubos .org/onlinefiles/uploads/ubos/UNHS_12_13/2012_13\%20UNHS\%20Final $\% 20$ Report.pdf

UBOS. (2019). 2018 Statistical Abstract. Retrieved from: https://www.ubos .org/wp-content/uploads/publications/05_2019STATISTICAL_ABSTRACT 2018.pdf

UNESCO. (2012). Education for All Global Monitoring Report Fact Sheet October 2012 Education in Kenya. Retrieved from: http://en.unesco.org/gem -report/sites/gem-report/files/EDUCATION_IN_KENYA_A_FACT_SHEET .pdf

United Republic of Tanzania. (2009). National Public Private Partnership (PPP) Policy, Prime Minister's Office. Retrieved from: https://ppp.worldbank.org/ public-private-partnership/sites/ppp.worldbank.org/files/documents/Tanzania PPP\%20Policy.pdf

Upper Quartile, \& IPAR - RWANDA. (2014). Evaluation of Results Based Aid in Rwandan Education - 2013 Evaluation Report. Retrieved from: https:/www .gov.uk/government/uploads/system/uploads/attachment_data/file/312006/ Rwanda-education-results-based-aid-evaluation.pdf

Urban Primary Education Advocacy Initiative. (2007). Falling Short: The Right to Free Primary Education. A Situational Analysis of Slums in Nairobi. Urban Primary Education Advocacy Initiative.

Urwick, J., \& Kisa, S. (2014). Science teacher shortage and the moonlighting culture: The pathology of the teacher labour market in Uganda. International Journal of Educational Development, 36, 72-80. 
Uwezo. (2015). Are our Children Learning? Five Stories on the State of Education in Uganda in 2015 and Beyond. Twaweza, East Africa: Uwezo.

Vavrus, F. (2002). Making distinctions: Privatisation and the (un)educated girl on Mount Kilimanjaro, Tanzania. International Journal of Educational Development, 22(5), 527-547.

Vavrus, F., \& Moshi, G. (2009). The cost of a "free" primary education in Tanzania, international critical childhood. Policy Studies, 2(1),31-42.

Verger, A. (2012). Framing and selling global education policy: The promotion of public-private partnerships for education in low-income contexts. Journal of Education Policy, 27(1), 109-130.

Vision 2030 Delivery Secretariat. (2018). Gender Sensitive Interventions and Voucher System (Establishment of the Voucher System. Vision 2030 Delivery Unit). Retrieved from: http://vision2030.go.ke/project/gender-sensitive -interventions-and-voucher-system/

Wambayi, O. N. (2004). Unit Cost of Basic Education - Kenya. Nairobi: Ministry of Education Science and Technology. Retrieved from: https://oris.nacosti.go .ke/modules/library/publications/research_reports/NACOSTI-DL-RR-1051 .pdf

Wane, W., \& Martin, G. H. (2013). Education and Health Services in UgandaData for Results and Accountability. Washington, DC: The World Bank.

Weaver, N. E. (2011). Educational Policy in Tanzania from Independence to the Present: Continuity and Transformation (Bachelor of Philosophy). University of Pittsburgh, USA.

Wedin, A. (2004). Literacy Practices in and out of School in Karagwe. The Case of Primary School Literacy Education in Rural Tanzania, Centre for Research on Bilingualism (Doctoral dissertation). Stockholm University, Sweden.

Wiegratz, J. (2019, 4 April). Capitalism and its discontents: My observations in Uganda and Kenya. The Elephant. Retrieved from: https://www.theelephant .info/ideas/2019/04/04/capitalism-and-its-discontents-my-observations-in -uganda-and-kenya/

Williams, T. P., Abbott, P., \& Mupenzi, A. (2015). "Education at our school is not free": The hidden costs of fee-free schooling in Rwanda. Compare: A Journal of Comparative and International Education, 45(6), 931-952.

Wilson-Strydoma, M., \& Okkolin, M. (2016). Enabling environments for equity, access and quality education post-2015: Lessons from South Africa and Tanzania. International Journal of Educational Development, 49, 225-233.

Woods, E. (2009). Progress towards EFA in Tanzania. Prospects, 38, 425-430.

World Bank. (2018a). Uganda Secondary Education Expansion Project (P166570). Project Information Document/ Integrated Safeguards Data Sheet. (PID/ISDS). Retrieved from: http://documents.worldbank.org/curated/ en/521301533884327735/pdf/Concept-Project-Information-Document -Integrated-Safeguards-Data-Sheet-Uganda-Secondary-Education-Expansion -Project-P166570.pdf

World Bank. (2018b). World Development Report 2018: Learning to Realize Education's Promise. Washington, DC: World Bank. Doi:10.1596/978-1 $-4648-1096-1$ 
Zollmann, J., \& Wanjala, C. (2016). Finance \& Fortune: The Role Financial Services Did - and Didn't - Play in the Life Trajectories of Financial Diaries Households. Nairobi, Kenya. Retrieved from: https://s3-eu-central-1 .amazonaws.com/fsd-circle/wp-content/uploads/2016/11/02134609/Finance -Fortune-report-final.pdf

Zuilkowski, S. S., Piper, B., Ong'ele, S., \& Kiminza, O. (2018). Parents, quality, and school choice: Why parents in Nairobi choose low-cost private schools over public schools in Kenya's free primary education era. Oxford Review of Education, 44(2), 258-274.

Zuze, T. L., \& Leibbrandt, M. (2011). Free education and social inequality in Ugandan primary schools: A step backward or a step in the right direction? International Journal of Educational Development, 31, 169-178. 